\title{
Endophytic interaction of Bacillus sp. in micropropagated banana plantlets
}

\author{
JOSIELE S. ROCHA ${ }^{1}$, SILVIA NIETSCHE ${ }^{2}$, MARLON C.T. PEREIRA ${ }^{1}$, MARIA $O$. \\ MERCADANTE-SIMÕES ${ }^{3}$, RAYANE C. SANTOS ${ }^{1}$ and ADELICAA. XAVIER ${ }^{1}$ \\ ${ }^{1}$ Programa de Pós-Graduação em Produção Vegetal no Semiárido, Universidade Estadual de \\ Montes Claros, Rua Reinaldo Viana, 2650, 39400-000 Janaúba, MG, Brazil \\ ${ }^{2}$ Instituto de Ciências Agrárias, Universidade Federal de Minas Gerais, Avenida Universitária, \\ 1000, Bairro Universitário, 39404-547 Montes Claros, MG, Brazil \\ ${ }^{3}$ Programa de Pós-Graduação em Biotecnologia, Universidade Estadual de Montes Claros, \\ Campus Professor Darcy Ribeiro, s/n, 39401-089 Montes Claros, MG, Brazil \\ Manuscript received on December 4, 2018; accepted for publication on February 28, 2019
}

\begin{abstract}
How to cite: ROCHA JS, NIETSCHE S, PEREIRA MCT, MERCADANTE-SIMÕES MO, SANTOS RC AND XAVIER AA. 2019. Endophytic interaction of Bacillus sp. in micropropagated banana plantlets. An Acad Bras Cienc 91: e20181295. DOI 10.1590/0001-3765201920181295.
\end{abstract}

\begin{abstract}
The banana tree is associated with different species of endophytic bacteria that can stimulate plant growth. However, further studies are needed to better understand the relationships between this group of bacteria and the host plant. The objective of this study was to investigate the localization of the EB-40 (Bacillus sp.) through anatomical and ultrastructural analyses in micropropagated banana plantlets. The results demonstrated the effective colonization of the EB-40 isolate in the intercellular and intracellular spaces, as well as in the rhizosphere region. The wall of endophytic bacteria contains calcium and nitrogen. The EB-40 isolate was also observed to associate with the plasma membrane and cell wall. These results further our understanding of the mechanisms involved in the colonization of plant cells by endophytic bacteria in micropropagated banana plantlets.
\end{abstract}

Key words: Endophytic bacteria, Musa spp., light microscopy, transmission electron microscopy.

\section{INTRODUCTION}

Plant development occurs through complex interactions between the plant and different environmental factors, among which biotic factors, especially microorganisms, play a key role. Endophytic microorganisms primarily colonize plants through natural openings, especially in the regions of lateral root emergence, substomatic cavities via stomatal openings, and through openings caused by injuries or by enzymes, such

Correspondence to: Silvia Nietsche

E-mail: silvia.nietsche@gmail.com

ORCid: https://orcid.org/0000-0002-8188-3057 as pectinases and cellulases (Reinhold-Hurek and Hurek 2011).

Inside the host, endophytic bacteria can be located at the point of entry or spread throughout the plant, residing within cells, in intracellular spaces or in the vascular system. While some strains of endophytic bacteria primarily colonize plant roots, others colonize roots and stems, while others colonize roots, stems and leaves (Santoyo et al. 2016).

A former study reported that endophytic bacteria have the ability to move freely in the cytoplasmic spaces of 'Grand Naine' banana leave cells (Thomas and Sekhar 2014). However, 
the authors noted that the manner in which this bacterium gains access to the intracellular niche has not yet been elucidated.

Numerous species of endophytic bacteria of the genus Bacillus have been reported to colonize banana tree (Kavino et al. 2007, Souza et al. 2013). The use of these microorganisms in banana crops has the potential to promote plant growth through the biological fixation of nitrogen, plant hormone production as well as protection against abiotic stresses (Zhang et al. 2011, Wang et al. 2013, Souza et al. 2016). Although studies have demonstrated the beneficial effects of the association of the genus Bacillus and banana trees, many questions have yet to be answered, specially a better understanding regarding how this intimate association starts and understand how it established.

Thus, the goal of this study was to investigate the interactions between the isolate EB-40 (Bacillus sp.) in the roots of the micropropagated bananas plantlets through anatomical and ultrastructural analyses.

\section{MATERIALS AND METHODS}

The apical meristems of the banana cultivar PrataAnã (triploid AAB) were obtained from developing suckers grown under field conditions and in vitro plant establishment and multiplication was carried out according to the methodology described by Israeli et al. (1995). Endophytic bacteria used in this study (EB-40, Bacillus sp./GQ340516.1) was isolated by Souza et al. (2013) and the biotechnological potential of which was previously evaluated by Andrade et al. (2014). The bacterial isolate was cultured on $20 \mathrm{~mL}$ of TSA (Tryptic Soy Agar) solid medium in Petri dish for 48 hours at 28 ${ }^{\circ} \mathrm{C}$. After bacterial growth was observed, colonies were harvested, and a bacterial suspension was in $0.85 \%$ sodium chloride $(\mathrm{NaCl})$ saline solution. The concentration of bacterial cells was adjusted using a spectrophotometer to an $\mathrm{OD}_{540}$ of 1.0.
After the in vitro establishment and multiplication stages of the explants (fifth replication), 20 explants were selected for the in vitro elongation and rooting process. The explants were inoculated in rooting medium containing 25 $\mathrm{mL}$ of Woody Plant Medium (WPM) (Lloyd and McCown 1980). After 20 days, inoculation was carried out using $2.0 \mathrm{~mL}$ of the bacterial suspension at the base of the rhizome. The final concentration of bacterial cells in the suspension was adjusted to $10^{8} \mathrm{CFU} / \mathrm{mL}^{-1}$ of the EB-40 isolate.

Thirty days after the inoculation, anatomical and ultrastructural analyses were performed on young root fragments located in the most distal part of the rhizome (Figure 1a-c). Photographic documentation was performed with the aid of a digital camera coupled to an Axion Cam ICC/Lab AI light microscope (Zeiss, Jena, Germany). For ultrastructural analyses, the samples were examined with a Tecnai G2-20 Supertwin transmission electron microscope (FEI Company, Eindhoven, Netherlands) at $200 \mathrm{Kv}$ and electron energy loss spectroscopy - EELS, for nitrogen and calcium analysis.

\section{RESULTS}

Intense bacterial cell aggregation was observed on the root epidermis surfaces, indicating abundant epiphytic colonization in the rhizoplane (Figure 2a). The EB-40 isolate appeared as rod-shaped cells that were joined in rows of two to three individual cells (Figure 2d) and were adhered to the rhizoplane, in close association with the walls of the root hairs. The presence of mucilaginous, polysaccharide fibrillar material was observed in the region of the rhizoplane and inside the root hairs (Figure 2e, f). Ultrastructure visualizations showed the presence of the EB-40 endophytic bacteria present in the intracellular environment (Figure 3a-1). Under the assayed conditions, the isolate was typically associated with the plasma membrane (Figure 3a, b) and the cellulosic wall (Figure 3 e-1). The EB-40 isolate exhibited a thick 

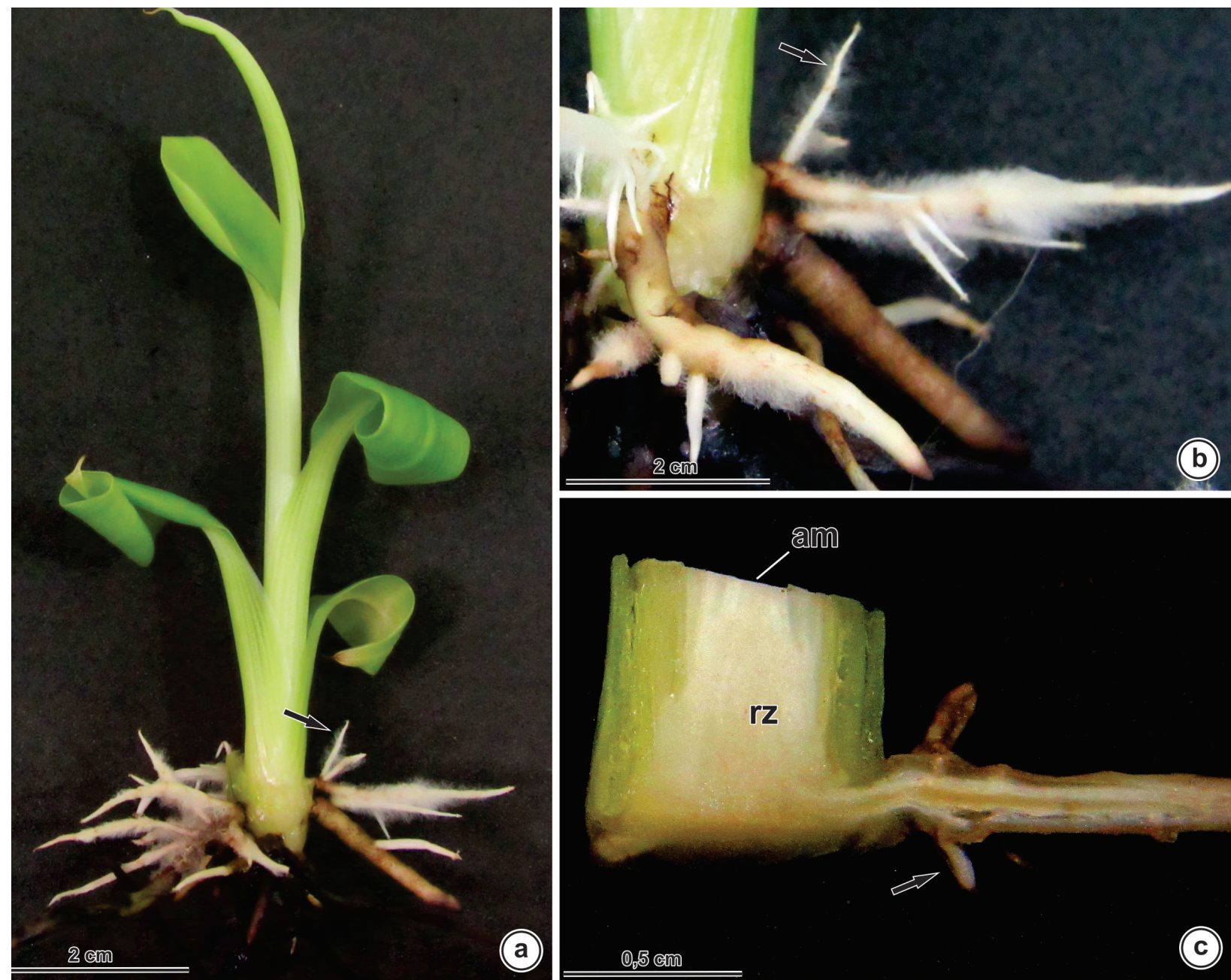

Figure 1- Morphology of the root system of a banana tree plantlet (cv. Prata-Anã) cultured in vitro in association with endophytic bacteria (Bacillus sp. isolate EB-40) (a, b and c). am, apical meristem; rz, rhizome.

wall and heterogeneous cytoplasm with regions of different electrodensity (Figure 3b-d, f, j, l). A mucilaginous material, similar in appearance to the cellulosic wall, was observed to be associated with the bacteria (Figure 3d). The wall of endophytic bacteria contains calcium (Figure $3 \mathrm{~g}$ ) and nitrogen (Figure 3h). An intimate association of the bacterial cells with the plant cell wall was observed that was sometimes associated with the wall dots (Figure 3j) or even crossing it (Figure 31).

\section{DISCUSSION}

The results of the present study demonstrated the ability of the EB-40 isolate of the genus Bacillus sp. to have both endophytic and epiphytic associations with the roots of the 'Prata-Anã' banana tree. The presence of mucilaginous material in trichomes is commonly cited in the literature as the preferred regions of bacterial development and infection by endophytic bacteria (Hallmann et al. 1997). The pattern of aggregation observed in bacterial cells in the rhizoplane is an indicator of biofilm formation. Biofilm formation contributes to bacterial persistence on the plant surface and functions as a signaling system between cells through quorum sensing systems (Gingichashvili et al. 2017). Thomas and Sekhar (2014), studied plant tissues of 'Grand Naine' banana trees and observed intense colonization by endophytic bacteria in the 

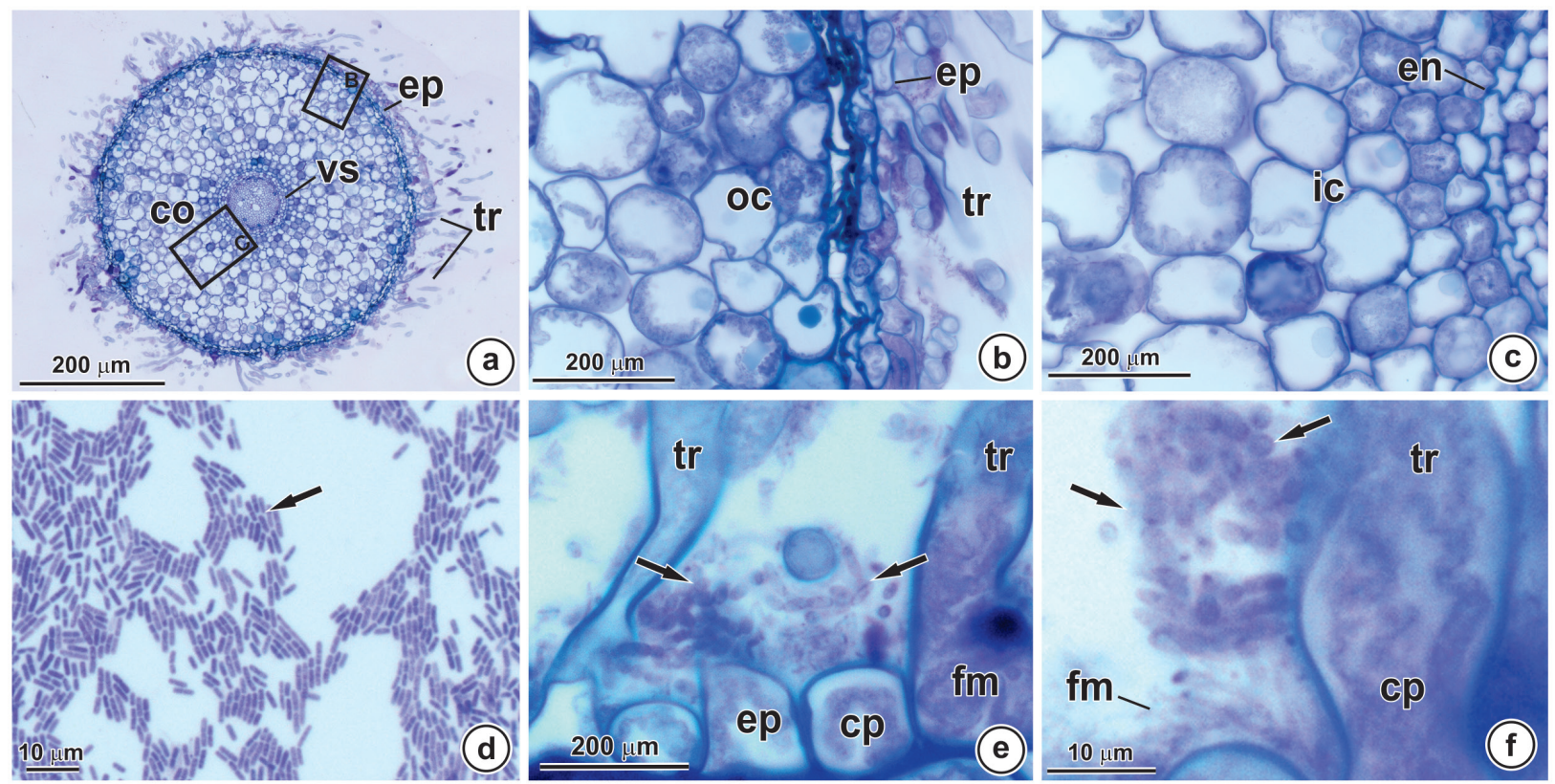

Figure 2 - Musa acuminata root ('Prata-Anã' AAB) cultivated in vitro and colonized by the isolate EB-40 (Bacillus sp.). Cross section of the median region. (a) Overview. (b) Detail of box B, marked in a. Unicellular, elongated root hairs with lignified walls. Biserial, pavimentous epidermis, with lignified walls. Outer layers of the cortex with small, bulky cells. Retracted protoplast. (c) Detail of box C, marked in a. Region of the aerenchymatous internal cortex. Endoderm with cells of suberized walls in all its extension. (d) Rod-shaped Bacillus sp. isolate EB-40 cells joined in rows of two to three cells. (e-f) A mucilaginous, fibrillar material in the rhizoplane and inside the root hairs. Caption: co: cortex; cp: cytoplasm; en: endoderm; ep: epidermis; fm: fibrillar material; ic: internal cortex; oc: outer cortex; tr: trichome; vs: vascular system. The arrows indicate the location of the bacteria.

cytoplasmic and periplasmic intracellular spaces of leaves. The authors noted that this level of colonization can be explained by the intracellular space and the rhizoplane presenting energy-rich sources of carbon that are exuded by the plant cells, explaining the preference of bacteria for these regions (Rosenblueth and Martínez-Romero 2006). Another important result observed was the presence of calcium-rich bacterial cell envelopes (Figure $3 \mathrm{~g}$ ). Calcium is a biologically important ion in the cell walls of bacteria, participating in synergistic interactions with enzymes responsible for the anchoring of surface proteins in the cell wall and also plays an important role in preserving the stability of external structures (Peshenko and Dizhoor 2007, Sahalan et al. 2013). In general, the cell walls of bacteria are rich in $\mathrm{Mg}^{2+}$ and $\mathrm{Ca}^{2+}$ ions, with the latter having a protective function against the activity of antimicrobial compounds that degrade the lipopolysaccharide layer (Sahalan et al. 2013). The results of the study provide direction for future studies, which should be done with the goal of elucidating the mechanisms by which endophytic bacteria move through the interior of the plants, from the rhizoplane to the cytoplasm of the cortical cells of roots. In addition, an understanding is needed of whether cells are preferentially trafficked in a symplastic or apoplastic manner, as well as if these microorganisms can transit through the elements of the vessel.

\section{ACKNOWLEDGMENTS}

The authors would like to thank Centro de Microscopia da Universidade Federal de Minas Gerais (UFMG) for the analysis of electron microscopy. Fundação de Amparo à Pesquisa do Estado de Minas Gerais - FAPEMIG, the Coordenação de Aperfeiçoamento de Pessoal 

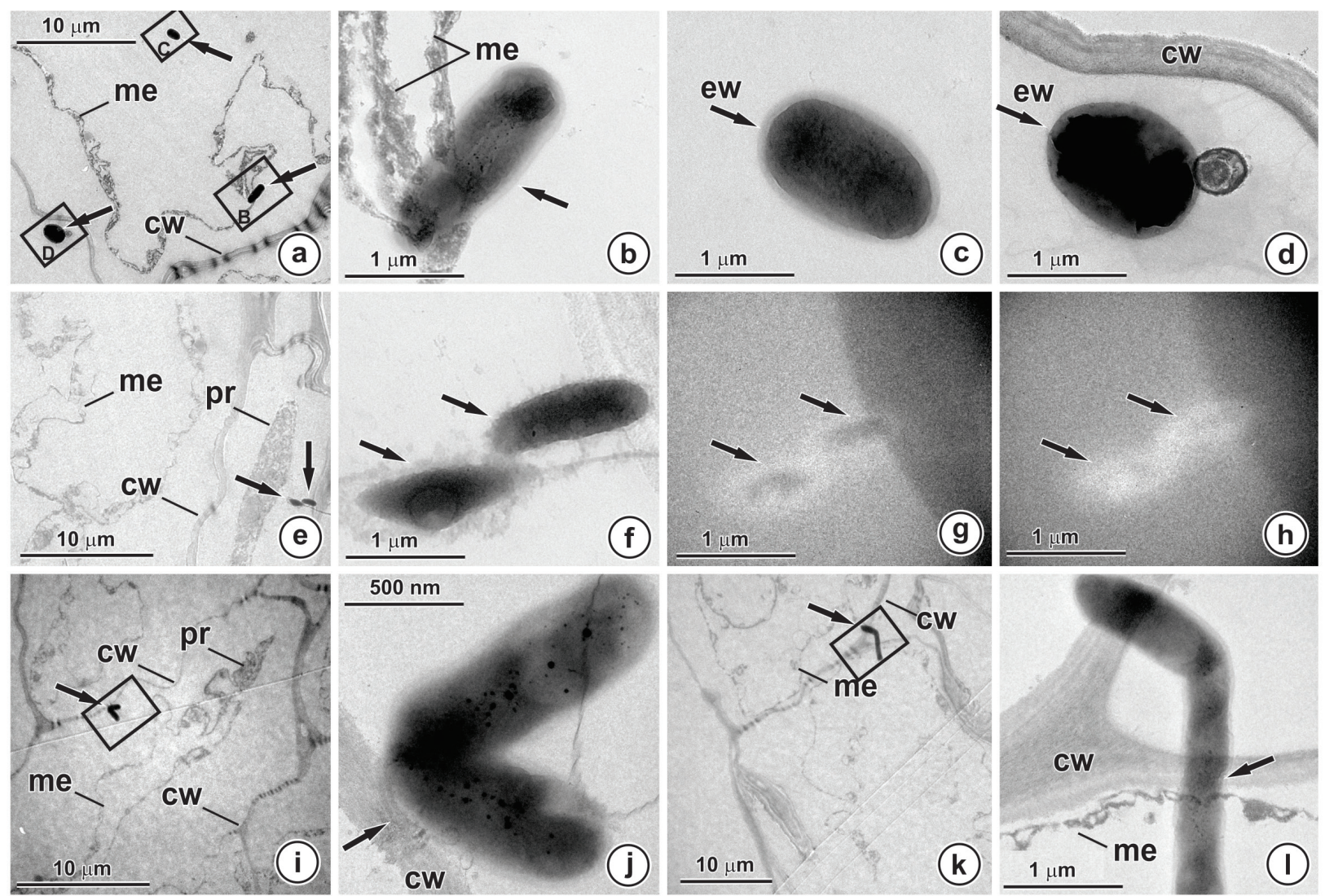

Figure 3 - Ultrastructure of cortical cells of Musa acuminata (Prata-Anã AAB) grown in vitro and colonized by endophytic bacteria. (a) (e) (f) (i) Bacillus sp. (EB-40 Isolate) present in the intracellular medium. Cells of the protoplast collapsed, retracted and separated from the plasma membrane of the cellulosic wall; (b) Detail of box B, labeled in a. Association of the EB-40 isolate with the plasma membrane; (c) detail of box C, labeled in a. The thick wall and heterogeneous cytoplasm of the endophyte; (d) Detail of box D, labeled a. Presence of mucilaginous material involving endophytes; (g) Detail of box g, labeled in e. Wall of EB-40 isolate with calcium; (h) Detail of box h, labeled in e. Wall of isolate EB-40 with nitrogen; (j) Detail of box j, marked in i. Intimate association of the EB-40 isolate with the cellulosic wall; (k) Association of the EB-40 isolate with the cellulosic wall; (l) Detail of box 1, labeled in k. The EB-40 isolate traversing the cell wall. Caption: cw: cellulosic wall; ew: endophytic wall; me: membrane; pr: protoplast.

de Nível Superior (CAPES) and the Conselho Nacional de Desenvolvimento Científico e Tecnológico (CNPq) for Research Productivity grants to MO Mercadante-Simões (304801/20160), S Nietsche and MCT Pereira.

\section{AUTHOR CONTRIBUTIONS}

SN, MCTP and MOMS conceived and designed research. JSR, RCS and AAX conducted experiments. MCTP, SN, RCS and MOMS analyzed data. SN, MOMS, JSR and AAX wrote the manuscript. All authors read and approved the manuscript.

\section{REFERENCES}

ANDRADE LF, SOUZA GLOD, NIETSCHE S, XAVIER AA, COSTA MR, CARDOSO AMS, PEREIRA MCT AND PEREIRA DFGS. 2014. Analysis of the abilities of endophytic bacteria associated with banana tree roots to promote plant growth. J Microbiol 52: 27-34.

GINGICHASHVILI S, DUANIS-ASSAF D, SHEMESH M, FEATHERSTONE JDB, FEUERSTEIN O AND STEINBERG D. 2017. Bacillus subtilis Biofilm development - a computerized study of morphology and kinetics. Front Microbiol 8: 1-9.

HALLMANN J, QUADT-HALLMANN A, MAHAFFEE WF AND KLOEPPER JW. 1997. Bacterial endophytes in agricultural crops. Can J Microbiol 43: 895-914. 
ISRAELI Y, LAHAV E AND REUVENI O. 1995. In vitro culture of bananas. Bananas and Plantains. Dordrecht: Springer Netherlands, 147-178.

KAVINO M, HARISH S, KUMAR N, SARAVANAKUMAR D, DAMODARAN T, SOORIANATHASUNDARAM K AND SAMIYAPPAN R. 2007. Rhizosphere and endophytic bacteria for induction of systemic resistance of banana treelets against bunchy top virus. Soil Biol Biochem 39: 1087-1098.

LLOYD G AND MCCOWN B. 1980. Tissue culture of rhododendrons and formulations of woody plant medium. Comb Proc Int Plant Prop Soc 30: 421-437.

PESHENKO IV AND DIZHOOR AM. 2007. Activation and inhibition of photoreceptor guanylyl cyclase by guanylyl cyclase activating protein 1 (GCAP-1): the functional role of $\mathrm{Mg}^{2+} / \mathrm{Ca}^{2+}$ exchange in EF-hand domains. J Biol Chem 282: $21645-21652$.

REINHOLD-HUREK B AND HUREK T. 2011. Living inside plants: bacterial endophytes. Curr Opin Plant Biol 14: 435443.

ROSENBLUETH M AND MARTÍNEZ-ROMERO E. 2006. Bacterial endophytes and their interactions with hosts. Mol Plant-Microbe In 19: 827-837.

SAHALAN AZ, AZIZ AHA, LIAN HH AND GHANI MKA. 2013. Divalent Cations $\left(\mathrm{Mg}_{2+}, \mathrm{Ca}_{2+}\right)$ Protect Bacterial Outer Membrane Damage by Polymyxin B. Sains Malaysiana 42: 301-306.
SANTOYO G, MORENO-HAGELSIEB G, OROZCOMOSQUEDA MDC AND GLICKC BR. 2016. Plant growth-promoting bacterial endophytes. Microbiol Res 183: 92-99.

SOUZA GLOD, NIETSCHE S, XAVIER AA, COSTA MR, PEREIRA MCT AND SANTOS MA. 2016. Triple combinations with PGPB stimulate plant growth in micropropagated banana plantlets. Appl Soil Ecol 103: 31 35.

SOUZA SA, XAVIER AA, COSTA MR, CARDOSO AMS, PEREIRA MCT AND NIETSCHE S. 2013. Endophytic bacterial diversity in banana "Prata Anã" (Musa spp.) roots. Genet Mol Biol 36: 252-264.

THOMAS P AND SEKHAR AC. 2014. Live cell imaging reveals extensive intracellular cytoplasmic colonization of banana by normally non-cultivable endophytic bacteria. AOB Plants 6: 1-12.

WANG B, YUAN J, ZHANG J, SHEN Z, ZHANG M, LI R, RUAN Y AND SHEN Q. 2013. Effects of novel bioorganic fertilizer produced by Bacillus amyloliquefaciens W19 on antagonism of Fusarium wilt of banana. Biol Fertil Soils 49: 435-446.

ZHANG N, WU K, HE X, LI X, ZHANG Z, SHEN B, YANG X, ZHANG R, HUANG Q AND SHEN Q. 2011. A new bioorganic fertilizer can effectively control banana wilt by strong colonization with Bacillus subtilis N11. Plant Soil 344: 87-97. 